\title{
Goserelin Acetate Extended-release Microspheres LY01005
}

National Cancer Institute

\section{Source}

National Cancer Institute. Goserelin Acetate Extended-release Microspheres LY01005.

NCI Thesaurus. Code C156710.

\begin{abstract}
A long-acting, extended-release microsphere formulation of the acetate form of goserelin, a synthetic decapeptide analog of luteinizing hormone-releasing hormone (LHRH), with potential antineoplastic activity. Upon administration, goserelin binds to and activates pituitary gonadotropin-releasing hormone $(\mathrm{GnRH})$ receptors. Prolonged administration of goserelin inhibits the secretion of pituitary gonadotropin, thereby decreasing levels of testosterone (in males) and estradiol (in females). Administration of this agent in an extended-release formulation may result in the regression of sex hormone-sensitive tumors and a reduction in sex org an size and function.
\end{abstract}

